\title{
An Empirical Study on Externality and Total Factor Productivity of Manufacturing Industry in China
}

\author{
Yiyao Zhang \\ School of Economics and Commerce, South China University of Technology, Guangzhou, China \\ Email: zhangyiyao20@163.com
}

How to cite this paper: Zhang, Y.Y. (2017) An Empirical Study on Externality and Total Factor Productivity of Manufacturing Industry in China. Open Journal of Social Sciences, 5, 269-275. https://doi.org/10.4236/jss.2017.53025

Received: March 1, 2017

Accepted: March 30, 2017

Published: April 6, 2017

\begin{abstract}
This paper uses the data provided by the China Economic Census Yearbook in 2004, 2008 and 2013 to measure the TFP of the whole manufacturing and labor-intensive, capital-intensive and technology-intensive industries of 29 provinces. By constructing spatial econometric model between externality of MAR, Jacobs, Porter and TFP, and the empirical outcome shows that only MAR externality has a significant negative effect on TFP of the whole manufacturing, that is, reducing the specialization of the manufacturing industry can improve the total factor productivity. At the same time, the specific effects of the three externalities on the TFP of the manufacturing industry will be different due to the different types of industries.
\end{abstract}

\section{Keywords}

Externalities, TFP, Classification of Manufacturing Industry, Spatial Econometric

\section{Introduction}

Industrial agglomeration has been a hot topic in the academic discussion, while the agglomeration externalities in which hold an important role. The discussion about externalities can be traced back to the Marshall (1890), in his view, the three reasons for agglomeration economy is the market of labor pool, intermediates and knowledge overflow. And The Theory of Endogenous Growth highlights the importance of knowledge spillover in economic growth. According to Tibor Scitovsky's [1] point, externality is usually divided into monetary externality and technical externality, monetary externality refers to the industry association, mainly through the price mechanism to reduce the enterprise cost, and technical externality is based on the technological spillover and diffusion of as- 
sociation [2]. New Economic Geography Theory mainly examines the monetary externalities in agglomeration, not talk much about the technology externality. According to the different sources, technical externalities can be divided into three types: Marshall externalities (MAR), Jacobs externalities (Jacobs), and Potter externalities (Porter).MAR externalities [3] [4] thinks that the knowledge spillover between same industries can promote technology progress and innovation. Also the regional monopoly hold a role in economic growth; Jacobs [5] insisted that the knowledge spillover happens in different industries can promote innovation and economic growth; Porter [6] argued that highly competitive in the same industry can promote technology innovation, and shared the same point with Jacobs that the regional monopoly hinders the technical progress.

Three kinds of externality have always caught the attention of scholars at home and abroad, and different scholars with different data and methods get different results. So the specific role of the three externalities has not yet written a conclusion. The empirical study on externality mainly focuses on the two aspects: one is to study the relationship between the three externalities and the regional or industrial economic growth, and the other is to explore impact of the externalities on innovation. In a study of externality in regional or industrial economic growth, Wu Sannang, Li Shan Tong [7] found the positive impact of MAR externality on manufacturing output growth. Xie Pin [8] revealed that there is an inverted U-shaped relationship between industry specialization and economic growth; Octávio Figueiredo et al. [9] found that MAR externality has a significant positive impact on the growth of the industry output, Also, some scholars found that MAR externality and Jacobs externality are good for economic growth [10] [11]. In this paper, the author points out that the localization of the industry has a positive effect on the industry. The On the externalities of empirical research on innovation, some scholars come to a similar result, found that MAR externality and Jacobs externality has a significant positive role in promoting for the industry or the enterprise level of innovation [12] [13] [14].

Based on TFP, we can measure the quality of economic growth more comprehensively. This paper chooses to study the influence of three kinds of externalities on the TFP of Chinese manufacturing industry. This paper divides manufacturing into labor-intensive, capital-intensive and technology-intensive industries, and uses the spatial measurement model to explain the relationship between externality and Chinese manufacturing Economic growth.

\section{Model Building, Variables and Data Description}

\subsection{Spatial Model}

In this paper, we refer to the research model of Miller, Upadhyay [15], Mao Qilin, Sheng Bin [16], what we get as follows.

$$
T F P_{i t}=A_{i 0} e^{\lambda_{t} t} M A R_{i t}^{\delta_{i}} \operatorname{Jacobs}_{i t}^{\theta_{i}} \text { Porter }_{i t}^{\gamma_{i t}}
$$

$A_{i 0}$ refers to initial productivity, $\lambda_{t}$ is the influence degree of exogenous variable to productivity, $\delta_{i}, \theta_{i}, \gamma_{i}$ are the degree of three externalities impacts technology. We get the logarithm of both sides, 


$$
\ln T F P_{\text {it }}=\ln A_{i 0}+\lambda_{t} t+\delta_{i} M A R_{\mathrm{it}} \theta_{i} \text { Jacobs }_{i t}+\gamma_{i} \text { Porter }_{\mathrm{it}}
$$

This paper mainly studies the influence of technology externalities on the TFP of manufacturing in China. At the same time, according to other literature, we choose the opening degree (open), the state capital ratio (stat) and the human capital (hr) as the control variables. The final measurement model is as follows:

$\ln T F P_{\mathrm{it}}=\alpha+\beta_{1} M A R_{\mathrm{it}}+\beta_{2}$ Jacobs $_{\mathrm{it}}+\beta_{3}$ Porter $_{\mathrm{it}}+\beta_{4}$ open $_{\mathrm{it}}+\beta_{3} h r_{\mathrm{it}}+\beta_{3}$ stat $_{\mathrm{it}}+\varepsilon_{\mathrm{it}}$

\subsection{Variables and Data Description}

For dependent variable. This paper chooses the Solow residual method to measure TFP. So this paper needs the output Y, labor input L and capital input K. we choose the total output, the number of employees, and the capital stock [11]; while Independent variable. In this paper, the majority of the literature selected by the location of the business to calculate MAR externality, we select the relative diversification index to express Jacobs externality. For Porter externalities, this paper chooses the use of $\mathrm{j}$ regional $\mathrm{i}$ industrial enterprise employees and the national $i$ industrial enterprises the ratio of the number of employees employed to measure.

According to the intensity of production factors, this paper will be divided into labor-intensive manufacturing, capital-intensive and technology-intensive three industries. This paper is based on the annual survey of China's economic census in 2003, 2008 and 2013, as well as three years of economic census bulletin, economic census yearbook and provincial statistical yearbook. The final research area includes 29 provinces (Tibet, Hainan and Hong Kong, Macao and Taiwan regions are not considered).

\section{Spatial Autocorrelation Test and Regression Analysis}

\subsection{Spatial Autocorrelation Test}

This article uses the Moran's I to test the global autocorrelation of TFP in 2004, 2008 and 2013. According to the 2004, 2008 and 2013 manufacturing TFP in 29 provinces in China, we can get Table 1 .

From the Table 1, The Moran's I index are positive and all through the 5\% significance level. This indicates that there is a significant positive spatial correlation among TFP in 29 provinces, that is, there is a significant spatial agglomeration effect.

\subsection{Regression Analysis}

According to Wald test and Housman test, we can find the most suitable model (Table 2).

Table 1. Moran's I index.

\begin{tabular}{cccc}
\hline Year & 2004 & 2008 & 2013 \\
\hline Moran's I & $0.413^{\star * \star}$ & $0.201^{\star *}$ & $0.410^{\star * *}$ \\
\hline
\end{tabular}


We can get the conclusion that the manufacturing industry as a whole, capital-intensive industries and technology-intensive industries are SDM fixed effect model, labor-intensive industries for the SAR random effects model.

It can be seen from Table 3 that the spatial lag regression coefficients are positive, indicating that there is a significant spatial spillover effect among the TFP in the neighboring regions. In terms of regression results, industrial specialization has a significant effect on the manufacturing sector as well as the three types of industries at the significance level of significance. The direction of labor-intensive and technology-intensive industries is positive, the manufacturing industry and the capital one is negative. Market competition in technology-intensive industries have a significant positive effect.

The results show that the spatial spillover effect of industry specialization is significant and the direction is negative, indicating the degree of industry specialization is hard to the growth of TFP. From the impact on the overall structure, the degree of industrial specialization has a significant negative effects on the TFP to the whole.

For labor-intensive industries, industry specialization has a positive effect on TFP growth, indicating that the local industrial specialization can promote the TFP growth near area. The specialization of industry in local area and the agglomeration of talent have the same effect on the TFP in other regions. The effect of the overall effect is the same to that of the direct effect; look from Table 4, we also get the results of capital-intensive industries. The direct effect of industry

Table 2. Test result.

\begin{tabular}{|c|c|c|c|c|c|c|}
\hline \multirow{3}{*}{ Wald test } & \multirow{2}{*}{\multicolumn{2}{|c|}{ SAR }} & manufacturing & labor & capital & technology \\
\hline & & & $25.41^{\star *}$ & 6.72 & $13.18^{\star *}$ & $11.14^{*}$ \\
\hline & \multicolumn{2}{|c|}{ SEM } & $17.95^{\star * *}$ & 10.36 & $20.34^{\star * *}$ & $21.41^{\star * \star}$ \\
\hline \multirow{4}{*}{ AIC test } & \multirow{2}{*}{ SAR } & AIC & - & 216.5124 & - & 301.6393 \\
\hline & & $\mathrm{BIC}$ & - & 241.1715 & - & 328.7642 \\
\hline & \multirow{2}{*}{ SEM } & AIC & - & 229.2241 & - & 303.7293 \\
\hline & & BIC & - & 253.8832 & - & 330.8543 \\
\hline
\end{tabular}

Table 3. Regression result

\begin{tabular}{ccccc}
\hline & $\begin{array}{c}\text { manufacturing } \\
\text { SDM fixed }\end{array}$ & $\begin{array}{c}\text { labor } \\
\text { SAR random }\end{array}$ & $\begin{array}{c}\text { capital } \\
\text { SDM fixed }\end{array}$ & $\begin{array}{c}\text { technology } \\
\text { SDM fixed }\end{array}$ \\
\hline mar & $-0.36^{* * *}$ & $1.59^{* *}$ & $-2.63^{* * *}$ & $5.66^{* * *}$ \\
jacobs & 0.275 & -0.04 & 0.028 & -0.179 \\
porter & -0.85 & -0.355 & 0.065 & $2.68^{* * *}$ \\
open & -4.65 & $-4.635^{* * *}$ & -2.03 & 1.44 \\
hr & 0.92 & 0.084 & 0.32 & 0.12 \\
sta & $-4.32^{* * *}$ & -2.87 & $-1.06^{*}$ & -0.98 \\
\hline
\end{tabular}


Table 4. Effect disintegration.

\begin{tabular}{cccccc}
\hline & & manufacturing & labor & capital & technology \\
\hline \multirow{2}{*}{ direct effect } & mar & $-0.438^{* * *}$ & $1.763^{* *}$ & $-2.592^{* * *}$ & $5.83^{* *}$ \\
& jacobs & 0.318 & -0.044 & 0.0318 & $-0.167^{* *}$ \\
& porter & -0.581 & -0.35 & 0.199 & $2.809^{* *}$ \\
& mar & -0.99 & $1.406^{*}$ & 0.131 & 0.884 \\
indirect effect & jacobs & 0.641 & -0.034 & 0.077 & 0.273 \\
& porter & 2.852 & -0.284 & 1.879 & 1.55 \\
& mar & $-1.428^{* * *}$ & $3.169^{* *}$ & -2.427 & $6.714^{* *}$ \\
total effect & jacobs & 0.959 & -0.078 & 0.109 & 0.106 \\
& porter & 2.271 & -0.634 & 2.08 & $4.36^{* *}$ \\
\hline
\end{tabular}

specialization is significant. The higher of the degree to specialization in the local industry, the greater inhibitory effect on the local TFP; from the point of technology-intensive industries, the local industrial specialization and market competition have a significant positive effect on the overall TFP growth, while industrial diversification has a negative impact. To the overall structure, industry specialization and the market competition environment has a significant role in promoting the TFP growth.

\section{Conclusions and Suggestions}

Through this paper, we find that the influence of the three externality to the whole manufacturing industry is not significant. Only the negative effect of the industry specialization is to reduce the overall factor productivity of the whole industry. The specific impact of the three externalities on the total factor productivity of the manufacturing industry will result in different results due to the different types of industries.

Increasing the level of specialization of the industry has a positive effect on the growth of the TFP to the labor-intensive industries. The main advantage of the labor-intensive industry lies in the labor force, because the geographically close, cooperative relations are close, and the labor force is within the region Liquidity, easier industrial technology spillovers, promote technical exchanges, more advanced production methods and skills can be quickly spread between enterprises, resulting in technological progress, reduce production costs, improve production efficiency; reduce industry specialization Has a positive impact on the growth of total factor productivity in capital-intensive industries. The advantage of capital-intensive industries is that capital resources are invested more, including fixed assets and current assets. Capital-intensive industries are geographically aggregated, which may lead to higher resource consumption and pollution tendencies, while environmental protection capacity and environmental recovery capacity are not synchronized with resource consumption and environmental pollution, resulting in negative externalities to the environment Production costs will increase, production efficiency is low; high industry spe- 
cialization and strong competitive environment is conducive to technology-intensive industries to improve the total factor productivity. The highly competitive environment caused by the aggregation of the same industry will cause the enterprise to have a sensitive effect on any action of the opponent's business. An enterprise's technological innovation will soon be understood by other enterprises. The gathering leads to the high-speed technology diffusion and new technology. The monopoly profits will soon disappear, so as to further stimulate the technological progress of enterprises, and each rival enterprise's technological progress are the pressure of enterprise development, but also the driving force of technological innovation, competition forced enterprises to take the initiative to develop Rather than passive absorption of other people's technology spillovers, passive absorption of other companies technology spillovers, imitation innovation in the time dimension will lag behind the competitors, cannot be foothold in the industry.

\section{References}

[1] Scitovsky, T. (1954) Two Concepts of External Economies. Journal of Political Economy, 62, 143. https://doi.org/10.1086/257498

[2] Liang, Q. and Qian, X. (2007) Externality and Agglomeration: A Literature Review. World Economy, 2, 84-96.

[3] Arrow, K. (1962) The Economic Implication of Learning by Doing. Review of Economics \& Statistics, 29. https://doi.org/10.2307/2295952

[4] Romer, P.M. (1986) Increasing Returns and Long-Run Growth. Journal of Political Economy, 94, 1002-1037. https://doi.org/10.1086/261420

[5] Jacobs (1969) The Economy of Cities. Vintage, New York.

[6] Porter, M. The Competitive Advantage of Nations. Competitive Intelligence Review.

[7] $\mathrm{Wu}, \mathrm{S}$. and Li, S.T. (2011) Specialization, Diversity and Industrial Growth. The Journal of Quantitative \& Technical Economics, 8, 21-34.

[8] Xie, P., Li, L.Z. and Zhao, L.C. (2013) An Empirical Study on Industrial Agglomeration, Regional Specialization and Economic Growth of Manufacturing Industry in Jiangxi Province. Economic Geography.

[9] Figueiredo, O., Guimarães, P. and Woodward, D. (2015) Industry Localization, Distance Decay, and Knowledge Spillovers: Following the Patent Paper Trail. Journal of Urban Economics, 89, 21-31. https://doi.org/10.1016/j.jue.2015.06.003

[10] Wei, S., Tang, D. and Sun, X. (2015) Local Economic Structure, Spatial Spillovers and Growth of Manufacturing Industries: Taking the Example of the Yangtze River Delta. Industrial Economics Research.

[11] Jin, C.Y. and Wang, W.Q. (2015) Industrial Agglomeration, Knowledge Spillover and Industrial Growth: An Empirical Analysis Based on Spatial Panel Data Model. Collected Essays on Finance and Economics, 1, 3-9.

[12] Dong, X. and Yuan, Y. (2014) Firm Innovation, Life Cycle and Agglomeration Economies. China Economic Quarterly, 13, 767-792.

[13] Peng, X. and Jiang, C. (2011) Industrial Agglomeration, Technological Spillovers and Regional Innovation: Evidences from China. China Economic Quarterly.

[14] Shen, N. and Zhao, Z.Y. (2014) Dynamic Agglomeration Externalities and Enterprise Innovation Ability. Science Research Management, 4, 1-9. 
[15] Miller, S.M. and Upadhyay, M.P. (1995) The Effects of Openness, Trade Orientation, and Human Capital on Total Factor Productivity. The European House of Cards: St. Martin's Press, 399-423.

[16] Mao, Q. (2012) Economic Opening, Regional Market Integration and Total Factor Productivity. China Economic Quarterly.

Submit or recommend next manuscript to SCIRP and we will provide best service for you:

Accepting pre-submission inquiries through Email, Facebook, LinkedIn, Twitter, etc. A wide selection of journals (inclusive of 9 subjects, more than 200 journals)

Providing 24-hour high-quality service

User-friendly online submission system

Fair and swift peer-review system

Efficient typesetting and proofreading procedure

Display of the result of downloads and visits, as well as the number of cited articles

Maximum dissemination of your research work

Submit your manuscript at: http://papersubmission.scirp.org/

Or contact jss@scirp.org 